\title{
Expression of adiponectin receptors 1 (AdipoR1) and 2 (AdipoR2) in the porcine pituitary during the oestrous cycle
}

\author{
Marta Kiezun, Anna Maleszka, Nina Smolinska, Anna Nitkiewicz and Tadeusz Kaminski
}

\begin{abstract}
Background: Adiponectin, protein secreted mainly by white adipose tissue, is an important factor linking the regulation of metabolic homeostasis and reproductive processes. The biological activity of the hormone is mediated via two distinct receptors, termed adiponectin receptor 1(AdipoR1) and adiponectin receptor 2 (AdipoR2). The present study analyzed mRNA and protein expression of AdipoR1 and AdipoR2 in the anterior (AP) and posterior (NP) pituitary of cyclic pigs.

Methods: The total of 20 animals was assigned to one of four experimental groups ( $n=5$ per group) as follows: days 2-3 (early-luteal phase), 10-12 (mid-luteal phase), 14-16 (late-luteal phase), 17-19 (follicular phase) of the oestrous cycle. mRNA and protein expression were analyzed using real-time PCR and Western Blot methods, respectively.
\end{abstract}

Results: The lowest AdipoR1 gene expression was detected in AP on days 10-12 relative to days 2-3 and 14-16 ( $p<$ 0.05). In NP, AdipoR1 mRNA levels were elevated on days 10-12 and 14-16 ( $p<0.05)$. AdipoR2 gene expression in AP was the lowest on days 10-12, and an expression peak occurred on days $2-3(p<0.05)$. In NP, the lowest $(p<0.05)$ expression of AdipoR2 mRNA was noted on days 17-19. The AdipoR1 protein content in AP was the lowest on days 17-19 $(p<0.05)$, while in NP the variations in protein expression levels during the oestrous cycle were negligible. AdipoR2 protein in AP was most abundant on days 10-12, and it reached the lowest level on days 2-3 and 17-19 of the cycle $(p<0.05)$. The presence of AdipoR2 protein in NP was more pronounced on days 10-12 $(p<0.05)$.

Conclusions: Our study was the first experiment to demonstrate that AdipoR1 and AdipoR2 mRNAs and proteins are present in the porcine pituitary and that adiponectin receptors expression is dependent on endocrine status of the animals.

Keywords: Adiponectin, Adiponectin receptor, Pituitary, Oestrous cycle, Pig

\section{Background}

Adiponectin, also termed Acrp30, apM1, GBP28 and AdipoQ, was first identified by four independent research groups [1-4]. This 30-kDa adipose tissue-derived hormone is highly abundant in human and mouse serum and shows an inverse correlation with the body mass index $[5,6]$. Adiponectin monomers have an amino-terminal collagenlike domain and a carboxy-terminal globular domain that generate trimers, hexamers and high-molecular-weight (HMW) multimers. Several studies have demonstrated

\footnotetext{
*Correspondence: tkam@uwm.edu.pl

Department of Animal Physiology, University of Warmia and Mazury in Olsztyn, Oczapowskiego 1A, 10-710, Olsztyn-Kortowo, Poland
}

that different multimeric forms can determine the activity of adiponectin [7-9]. The discussed protein acts via AMPactivated protein kinase (AMPK) to modulate glucose and lipid metabolism [10]. It is also known for its protective role in obesity-related disorders, such as insulin resistance, type 2 diabetes mellitus and atherosclerosis [6,11], as well as in carcinogenesis [12]. A beneficial effect of adiponectin on female reproductive function was also suggested [13].

Two distinct adiponectin receptors (AdipoR1, AdipoR2) are seven-transmembrane domain receptors with an extracellular carboxyl terminus and an intracellular amino terminus, thus they are opposite to the topology of other G-coupled protein receptors. AdipoR1 shows high-affinity 
for the globular form of adiponectin, and AdipoR2 has an intermediate affinity for both full-length and globular species. Both adiponectin receptors are highly related and share $66.7 \%$ sequence identity in mice [14]. AdipoR1 and AdipoR2 are widely expressed, which suggests that adiponectin has pleiotropic effects. The highest expression of type 1 adiponectin receptor is noted in human, murine, porcine and chicken skeletal muscles, and the highest expression of type 2 adiponectin receptor is observed in the liver of the above forms [14-16]. The third putative adiponectin receptor, T-cadherin (cadherin 13, CDH13), is a molecule that lacks the transmembrane and cytoplasmatic domains and is bound to the surface membrane through a glycosylphosphatidylinositol anchor. The expression of T-cadherin was observed to confer binding of hexameric and HMW multimers but not trimeric adiponectin. It is also postulated that it may compete with AdipoRs for adiponectin binding or interfere with adiponectin signal transduction [17].

It has long been recognized that reproductive function is closely associated with energy balance, and metabolic dysregulation is linked with reproductive abnormalities. Neumeier et al. [18] reported that adiponectin is able to cross the blood-brain barrier, also subsequent studies showed that both AdipoRs and adiponectin are expressed in the human and rat brain and pituitary [19-21]. Adiponectin seems to be involved in autocrine/paracrine control of pituitary somatotrophs and gonadotrophs and secretion of GH, LH and FSH $[19,21]$. Thus, one can assume that adiponectin affects secretion of ovarian steroid hormones. However, there is lack of data describing the inverse relationship, i.e. the influence of hormonal status of animals, typical for each phase of the oestrous cycle, on pituitary adiponectin system expression. To our knowledge, no research has investigated the expression of the adiponectin receptors in the anterior (AP) and posterior (NP) pituitary of pigs during the cycle. The aim of this study was to compare the expression of AdipoR1 and AdipoR2 in the AP and NP of pigs at four stages of the oestrous cycle with the use of real-time PCR and Western blotting techniques.

\section{Methods}

\section{Experimental animals and tissue collection}

The studies were carried out in accordance with the principles and the procedures of the Animal Ethics Committee at the University of Warmia and Mazury in Olsztyn. Mature gilts (Large White $\times$ Polish Landrace) at 7-8 months of age, with body weight of $120-130 \mathrm{~kg}$, descended from private breeding, were used. The total of 20 animals was assigned to one of four experimental groups ( $\mathrm{n}=5$ per group) as follows: days $2-3$ (early-luteal phase), 10-12 (mid-luteal phase), 14-16 (late-luteal phase), 17-19 (follicular phase) of the oestrous cycle.
Females were monitored daily for oestrus behaviour in the presence of an intact boar. The onset of the second oestrus was marked as day 0 of the oestrous cycle. Phase of the oestrous cycle was also confirmed on the basis of morphology of the ovary [22]. To confirm correctness of the evaluation of the oestrous cycle phase, the level of progesterone $\left(\mathrm{P}_{4}\right)$ was determined as described by Nitkiewicz et al. [23]. The plasma level of $\mathrm{P}_{4}$ on days 2$3,10-12,14-16$, and 17-19 was as follows: $4 \pm 2 \mathrm{ng} / \mathrm{ml}$, $19 \pm 3.4 \mathrm{ng} / \mathrm{ml}, 8 \pm 2.2 \mathrm{ng} / \mathrm{ml}$, and $0.2 \pm 0.03 \mathrm{ng} / \mathrm{ml}$, respectively, and corresponds with earlier published data pertaining to the steroid concentration in pig plasma during the oestrous cycle [24]. Within a few minutes after slaughter the pituitary gland, muscle and liver were removed. Next, pituitary gland was separated into anterior and posterior lobes. All of the samples were frozen in liquid nitrogen and stored at $-80^{\circ} \mathrm{C}$ until processing for RNA and protein analysis. The same samples of tissues were used for RNA and protein isolation.

\section{Total RNA isolation and CDNA synthesis}

Total RNA was extracted from all collected tissues using the Absolutely RNA Miniprep Kit (Stratagene, USA). RNA concentration and quality were determined spectrophotometrically (NanoDrop ND-1000, NanoDrop Technologies Inc., USA). The entire total RNA was intact with high quality, i.e. optical density (O.D.) 260/280 and 260/230 ratios were between 1.8 and 2.0 and 1.8 or greater, respectively. Approximately $1 \mu \mathrm{g}$ of RNA was reverse transcribed into cDNA in a total volume of $20 \mu \mathrm{l}$ with $0.5 \mu \mathrm{g}$ oligo $(\mathrm{dT})_{15}$ primer (Roche, Germany) using Omniscript RT Kit (Qiagen, USA) at $37^{\circ} \mathrm{C}$ for $1 \mathrm{~h}$ and was terminated by incubation at $93^{\circ} \mathrm{C}$ for $5 \mathrm{~min}$.

\subsection{Quantitative real-time PCR}

Quantitative real-time PCR analysis was performed using a PCR System 7300 (Applied Biosystems, USA) with SYBR Green. Forward and reverse primers were selected according to Lord et al. [15]: AdipoR1, forward: 5'-GCCATGGAGAAGATGGAGGA-3', reverse: 5'-AGC ACGTCGTACGGGATGA-3'; AdipoR2, forward: $5^{\prime}$-TGT TCGCCACCCCTCAGTAT-3', reverse: 5'-AATGATTCC ACTCAGGCCCA-3'; cyclophilin A, forward: 5'-GCAC TGGTGGCAAGTCCAT-3', reverse: 5'-AGGACCCGTA TGCTTCAGGA-3'. AdipoR1 primers (access no: AY45 2710) were complementary to positions 148-168 (F) and 204-222 (R) of pig AdipoR1 gene sequence, AdipoR2 primers (access no: AY452711) were complementary to positions 322-341 (F) and 373-392 (R) of pig AdipoR2 gene sequence, cyclophilin A primers (access no: AY266299) were complementary to positions 219-237 (F) and 269-299 (R) of porcine cyclophilin A gene sequence. The constitutively expressed gene, cyclophilin A, was used as the internal control to verify the quantitative real-time 
PCR. During the preliminary experiments it was found that expression of cyclophilin A mRNA was very similar in both lobes of the pituitary and was stable during the oestrous cycle. The PCR reaction included $20 \mathrm{ng}$ cDNA, 300 nM (AdipoR1 forward, cyclophilin A forward and reverse), $50 \mathrm{nM}$ (AdipoR1 reverse, AdipoR2 forward and reverse) primers, $12.5 \mu \mathrm{l}$ SYBR Green PCR Master Mix (Applied Biosystems, USA), and RNase free water in a final volume of $25 \mu \mathrm{l}$. Quantitative real-time PCR cycling conditions were as follows: $50^{\circ} \mathrm{C}$ for $2 \mathrm{~min}$, then $95^{\circ} \mathrm{C}$ for $10 \mathrm{~min}$ for initial denaturation and enzyme activation, followed by 40 cycles of denaturation at $95^{\circ} \mathrm{C}$ for $15 \mathrm{~s}$, and annealing at $60^{\circ} \mathrm{C}$ for $1 \mathrm{~min}$. Negative controls were performed using water as a substitute for CDNA, or reverse transcription was not performed prior to PCR. All samples were amplified in duplicate. The specificity of amplification was tested at the end of the PCR by melting-curve analysis. Product purity was confirmed by electrophoresis. Calculation of relative expression levels of AdipoR1 and AdipoR2 was conducted based on the comparative cycle threshold method $\left(\Delta \Delta \mathrm{C}_{\mathrm{T}}\right)$ [25]. Expression of AdipoR1 and AdipoR2 was calculated by the equation $2^{-\Delta \Delta C T}$, where $\Delta C_{T}$ was obtained by subtracting the corresponding cyclophilin $\mathrm{A}$ $\mathrm{C}_{\mathrm{T}}$ value from specific $\mathrm{C}_{\mathrm{T}}$ of the target (AdipoR1 or AdipoR2, and $\Delta \Delta C_{\mathrm{T}}$ was determined by subtracting the $\Delta C_{\mathrm{T}}$ of each experimental sample from $\Delta C_{\mathrm{T}}$ of the reference sample, called the calibrator (the tissue with the lowest expression).

\section{Western blotting}

Western blotting analysis was performed essentially as described by Smolinska et al. [26]. Briefly, equal amounts of porcine pituitary lysates (anterior and posterior parts separately, $10 \mu \mathrm{g}$ of total proteins) were resolved by SDS-PAGE (12.5\%) for separating AdipoR1, AdipoR2 and actin and transferred to nitrocellulose membranes (Whatman, USA). Blots were blocked for $5 \mathrm{~h}$ at $4^{\circ} \mathrm{C}$ in Tris-buffered saline Tween-20 containing 5\% skimmed milk powder, then incubated overnight at $4{ }^{\circ} \mathrm{C}$ with the rabbit polyclonal adiponectin receptor 1 antibodies at a dilution of 1:150 (Phoenix Pharmaceuticals, USA), rabbit polyclonal adiponectin receptor 2 antibodies (Phoenix Pharmaceuticals, USA) at a dilution of 1:200, or rabbit polyclonal actin antibodies (Sigma, USA) diluted 1:200, which were used as an internal control for equal loading as well as to quantify porcine AdipoR1 and AdipoR2 proteins. To identify immunoreactive bands, membranes were incubated for $1.5 \mathrm{~h}$ at room temperature with mouse anti-rabbit IgG for AdipoR1 (Sigma, USA; diluted 1:2000), goat anti-rabbit IgG for AdipoR2 (Santa Cruz Biotechnology, USA; diluted 1:500) or goat anti-rabbit IgG for actin conjugated with alkaline phosphatase (Santa Cruz Biotechnology, USA; diluted 1:5000). Nonspecific foetal calf serum (MP Biomedicals, USA) was used instead of primary antibodies to produce negative control blots. The immunocomplexes were visualized using 4-nitroblue tetrazolium chloride (NBT) and 5-bromo-4-chloro-3indolyl phosphate (BCIP), according to the manufacture's protocol (Promega, USA). The same procedures were used for preparing positive controls-skeletal muscle and liver (for AdipoR1 and AdipoR2, respectively). The results of Western blotting were quantified by densitometric scanning of immunoblots with GelScan for Windows ver. 1.45 software (Kucharczyk, Poland). Data were expressed as ratio of AdipoR1 or AdipoR2 protein relative to actin protein in arbitrary optical density units.

\section{Data analysis}

Data are presented as means \pm S.E.M. from five different observations. Differences between groups were analysed by two-way ANOVA followed by least significant differences (LSD) post-hoc test. Statistical analyses were performed using Statistica Software (StatSoft Inc., Tulsa, USA). Values for $p<0.05$ were considered statistically significant.

\section{Results}

\section{Quantitative real-time PCR}

In AP, the lowest AdipoR1 mRNA levels were reported on days $10-12(p<0.05)$ compared to days $2-3$ and $14-16$, whereas in NP, higher levels of AdipoR1 mRNA were noted on days $10-12$ and $14-16(p<0.05)$ (Figure $1 \mathrm{~A}$ and $\mathrm{B})$. AdipoR2 gene expression in AP was the highest on days $2-3(p<0.05$ in relation to days $10-12$ and $14-16)$, and it was the lowest on days 10-12 of the oestrous cycle $(p<0.05)$ (Figure 2A). The level of AdipoR2 mRNA in NP was markedly lower on days $17-19(p<0.05$ relative to the remaining periods of the cycle) (Figure 2B). mRNA transcripts for both AdipoR1 and AdipoR2 were higher in NP than in AP on days 10-12 and 14-16 ( $p<$ $0.05)$; the differences between AP and NP were not significant during the remaining stages of the oestrous cycle (Figures $1 \mathrm{C}$ and $2 \mathrm{C}$ ).

\section{Western blotting}

AdipoR1 protein levels in AP were lowest on days 17-19 $(p<0.05)$, and no differences were observed between the remaining periods (Figure $3 \mathrm{~A}$ ). In NP, the variations in protein expression during the oestrous cycle were negligible (Figure 3B). AdipoR1 protein concentrations were higher in AP than in NP on days 2-3, 10-12 and 14-16 $(p<0.05)$ of the oestrous cycle (Figure 3C). AdipoR2 protein in AP was most abundant on days 10-12, and its levels were lowest on days $2-3$ and $17-19$ of the cycle $(p<0.05)$ (Figure $4 \mathrm{~A})$. The presence of AdipoR2 protein in NP was more pronounced on days 10-12, and it reached the lowest level on days $2-3 \quad(p<0.05)$ (Figure 4B). AdipoR2 protein was also more abundant in 


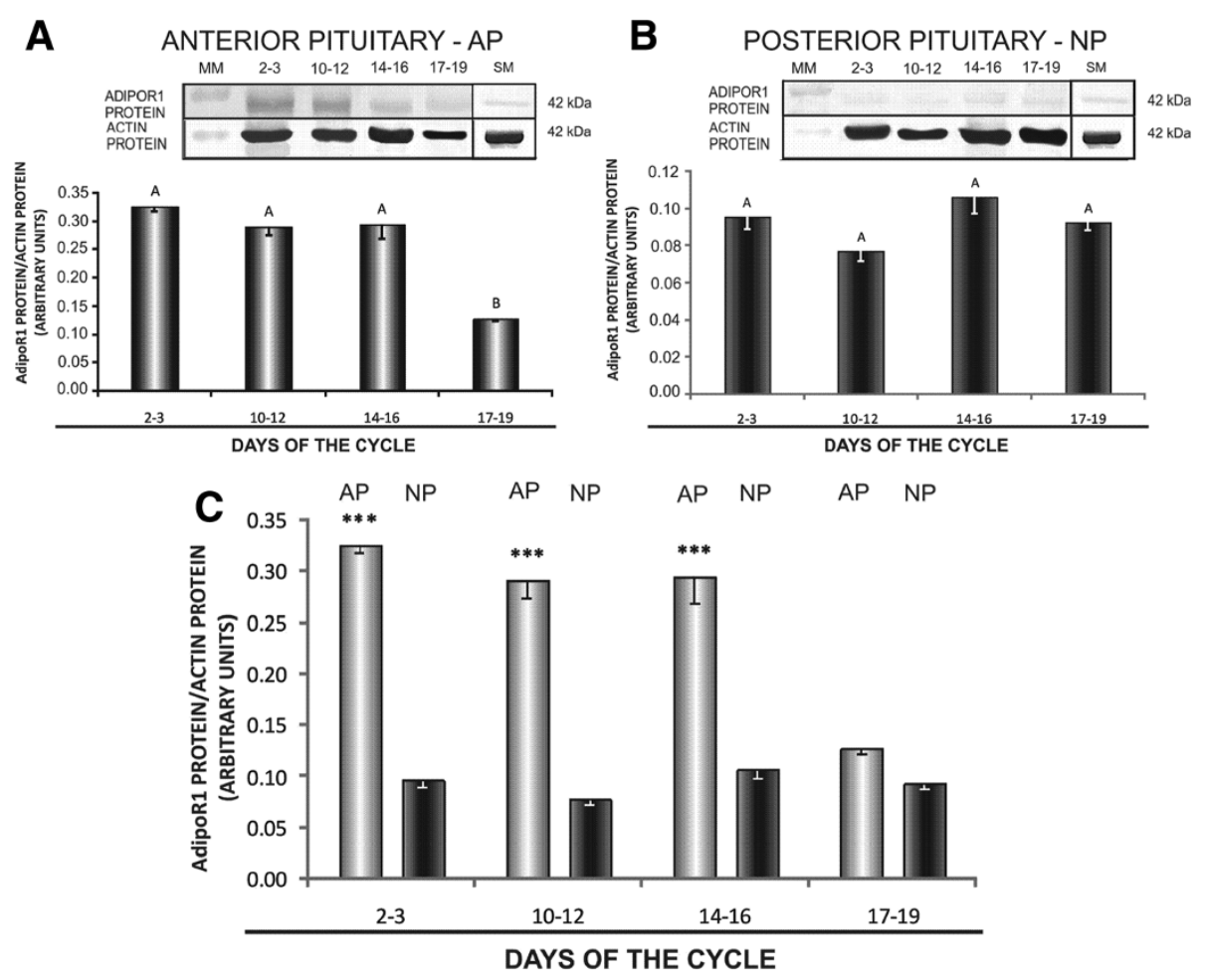

Figure 1 Expression of AdipoR1 mRNA in the anterior and posterior pituitary. Comparison of adiponectin receptor 1 (AdipoR1) mRNA expression determined by quantitative real-time PCR in porcine anterior (A) and posterior (B) pituitary glands between days 2-3, 10-12, 14-16 and 17-19 of the oestrous cycle, and (C) between anterior and posterior pituitary glands on days 2-3, 10-12, 14-16 and 17-19 of the cycle. Results are means \pm S.E.M. $(n=5)$. Bars with different superscripts are significantly different. Capital letters indicate $p<0.05 ;{ }^{* *} p<0.01 ;{ }^{* * *} p<$ 0.001 .

AP than in NP on days $14-16(p<0.05)$, and higher levels of expression were noted in NP than in AP on days 17-19 $(p<0.05)$ of the oestrous cycle (Figure 4 C).

\section{Discussion}

Our study was the first experiment to demonstrate the level of AdipoR1 and AdipoR2 genes transcripts and proteins in both anterior and posterior pituitaries of cyclic gilts. We found that the stage of the oestrous cycle affects the abundance of mRNAs and proteins of both adiponectin receptors. The abundance of AdipoR1 and AdipoR2 mRNAs varied throughout the oestrous cycle, with a marked decrease in AdipoR1 levels on days 1012 in AP and an increase on days $10-12$ and $14-16$ in NP. By contrast, AdipoR2 transcript content was higher on days 2-3 and 17-19 in AP and during the entire luteal phase in NP. Unlike the level of the AdipoR1 mRNA, the content of AdipoR1 protein was elevated during the entire luteal phase in AP, but it did not differ in NP during the oestrous cycle. AdipoR2 protein concentrations in AP and NP reached the highest level on days 10-12 of the oestrous cycle. Indicated in the study, lack of correlation between the protein concentration and gene transcripts may result from transcriptional regulation, post-transcriptional regulation (RNA processing and stability), translation regulation or protein stability, as well as functioning feedbacks, i.e. high protein concentration may suppress mRNA expression, and a high level of gene expression may diminish the posttranscriptional processes. The low concentration of protein with the simultaneous high gene expression level can also be caused by the action of interference RNA (RNAi). The above suggests that tissue mRNA and protein levels are determined by physiological state, and they are not always correlated.

There is a scarcity of data regarding adiponectin system (adiponectin and adiponectin receptors) expression in the pituitary. The presence of mRNA for all system components has been reported only in male rats [20,21], humans [21] and chickens [16]. Adiponectin receptor genes are also expressed by somatotroph cells isolated from transgenic GFP expressing mice, the GH3 cell line (rat pituitary tumor cell line) and L $\beta \mathrm{T} 2$ immortalized mouse gonadotrophs [20,27]. The presence of adiponectin, AdipoR1 and AdipoR2 proteins in the human pituitary has been demonstrated by immunohistochemical methods. Interestingly, Psilopanagioti et al. [19] observed 


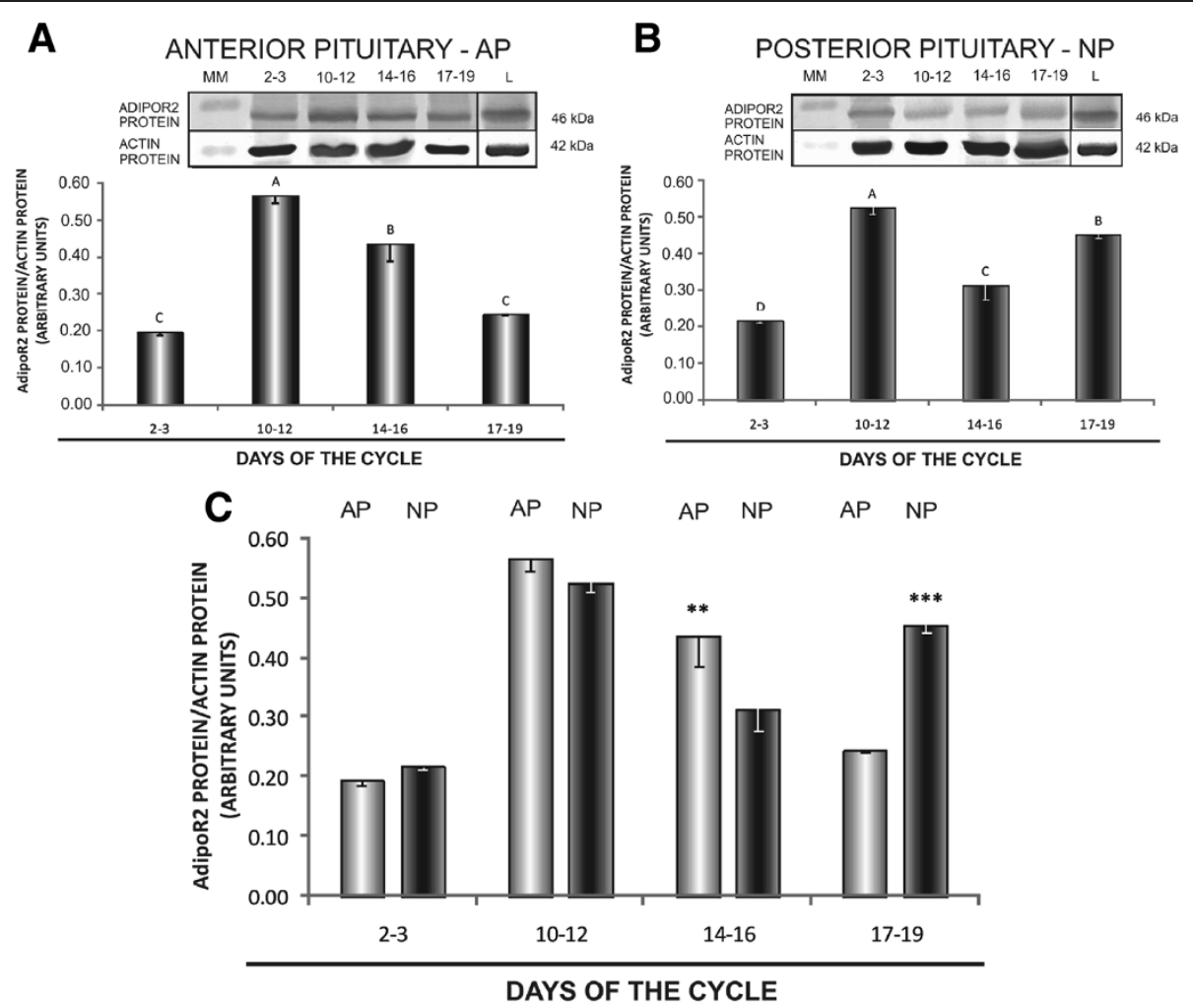

Figure 2 Expression of AdipoR2 mRNA in the anterior and posterior pituitary. Comparison of adiponectin receptor 2 (AdipoR2) mRNA expression determined by quantitative real-time PCR in porcine anterior $(\mathbf{A})$ and posterior (B) pituitary glands between days 2-3, 10-12, 14-16 and 17-19 of the oestrous cycle, and (C) between anterior and posterior pituitary glands on days 2-3, 10-12, 14-16 and 17-19 of the cycle. Results are means \pm S.E.M. $(n=5)$. Bars with different superscripts are significantly different. Capital letters indicate $p<0.05 ;{ }^{* *} p<0.01 ;{ }^{* * *} p<0.001$.

the colocalization of AdipoRs with gonadotrophs, somatotrophs and thyrotrophs, but not with corticotrophs or lactotrophs. Our study provides the first documented evidence of the expression of adiponectin receptors in the anterior and posterior lobes of the porcine pituitary during the oestrous cycle. The expression of the adiponectin in the studied endocrine gland was also determined (Kaminski et al., data not shown). The presence of both ligand and receptors in porcine pituitary may suggest adiponectin's auto-/paracrine role in the regulation of the gland function.

The noted variations in the expression of AdipoRs during the cycle suggest a correlation with the animals' hormonal milieu, primarily at the level of steroid hormones. Heightened levels of AdipoR1 and AdipoR2 mRNAs in the posterior lobe and lowered concentrations in the anterior lobe of the porcine pituitary during the luteal phase of the oestrous cycle could be attributed to ovarian hormones. The up-regulating effects of progesterone on AdipoRs transcripts in NP and its downregulating effects in AP cannot be ruled out. This hypothesis seems to be confirmed by the results of Takemura et al. [28] who observed a similar pattern of AdipoRs mRNA expression in the human endometrium and attributed their findings to endometrial changes during the implantation period. In a study of rat placenta during gestation, Caminos et al. [29] noted that progesterone had a stimulating effect on AdipoR2 gene expression. In addition to progesterone, oestradiol could be yet another ovarian hormone to be involved in AdipoRs expression. Tabandeh et al. [30] postulated that enhanced expression of adiponectin receptors in theca, granulosa and cumulus cells of bovine ovarian follicles, especially in late stages of follicular growth, could result from increased oestradiol concentrations in follicular fluid. Lagaly et al. [31] reported a similar trend in AdipoR2 gene expression in theca cells from large follicles of beef cattle. Interestingly, Tan et al. [32] observed that oestradiol and testosterone increase AdipoRs mRNA and protein levels in cultured human adipocytes. An in vitro study of 3 T3-L1 cells (differentiated into adipocyte-like phenotype) revealed an increase in AdipoR1 and AdipoR2 gene transcript levels after oestradiol treatment [33]. It has also been suggested that other factors, like insulin, prolactin, growth hormone or cytokines, may influence the abundance of AdipoRs [34-36]. Interestingly, several authors have suggested that adiponectin could be an important factor in 

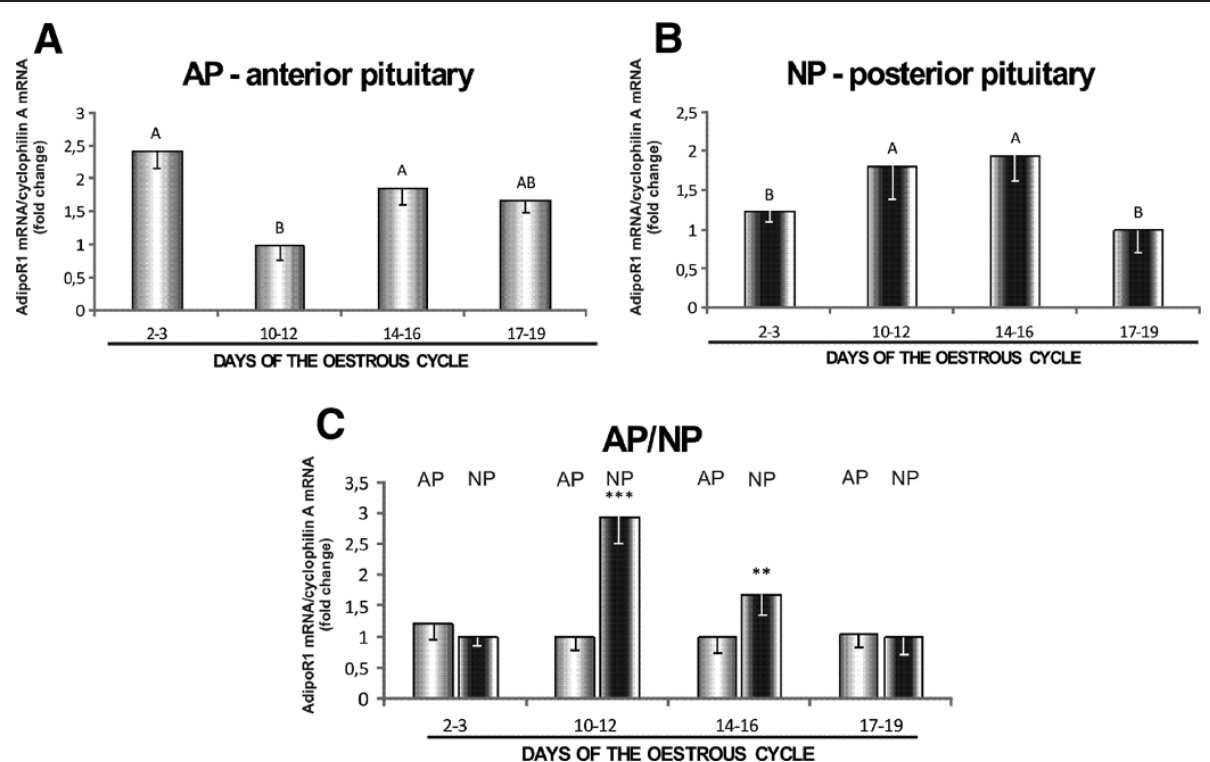

Figure 3 Expression of AdipoR1 protein in the anterior and posterior pituitary. A comparison of the expression levels of adiponectin receptor 1 (AdipoR1) protein determined by Western blotting analysis in porcine anterior (A) and posterior (B) pituitary glands between days 2-3, 10-12, 14-16 and 17-19 of the oestrous cycle, and (C) between anterior (AP) and posterior (NP) pituitary glands on days 2-3, 10-12, 14-16 and 17-19 of the cycle. Upper panels: representative immunoblots (MM, molecular marker; SM, skeletal muscles-positive control); lower panels: densitometric analysis of adiponectin receptor 1 protein relative to actin protein. Values are expressed as means \pm S.E.M. in arbitrary optical density units $(n=5)$. Bars with different superscripts are significantly different. Capital letters indicate $p<0.05 ;{ }^{* * *} p<0.001$.
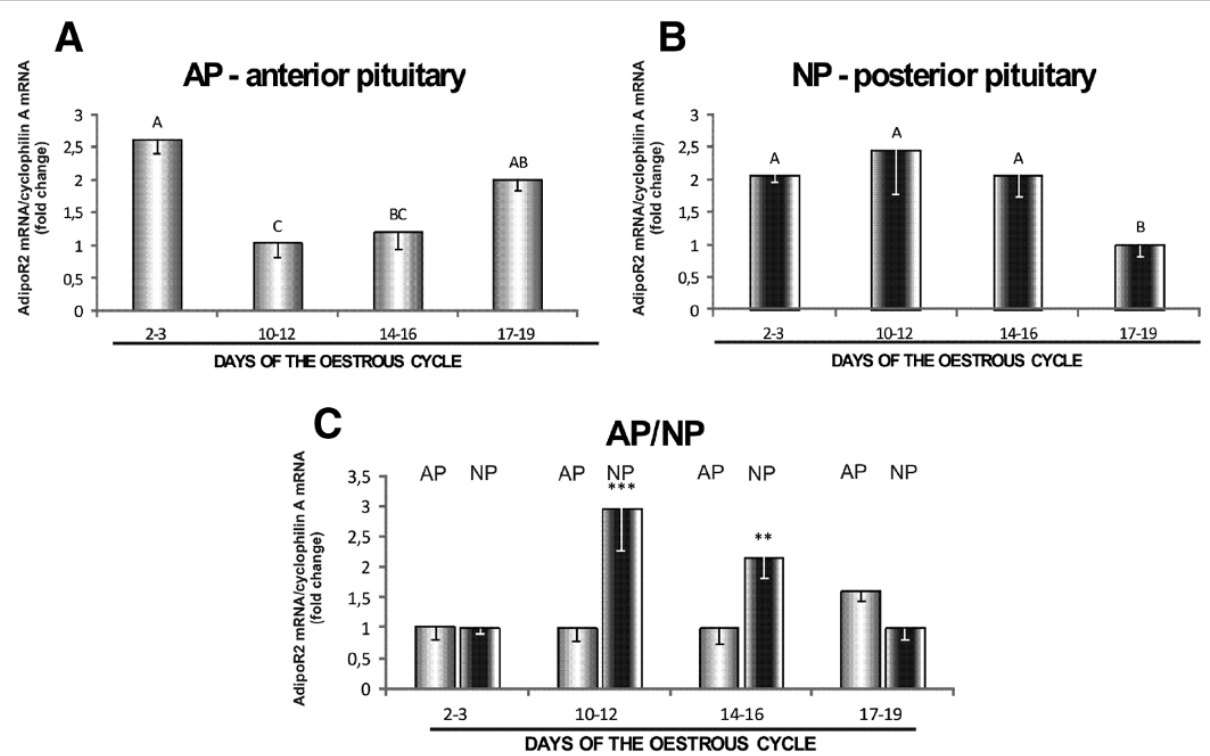

Figure 4 Expression of AdipoR2 mRNA in the anterior and posterior pituitary. Comparison of adiponectin receptor 2 (AdipoR2) protein expression determined by Western blotting analysis in porcine anterior (A) and posterior (B) pituitary glands between days 2-3, 10-12, 14-16 and 17-19 of the oestrous cycle, and (C) between anterior and posterior pituitary glands on days 2-3, 10-12, 14-16 and 17-19 of the cycle. Upper panels: representative immunoblots (MM, molecular marker; L, liver-positive control); lower panels: densitometric analysis of adiponectin receptor 2 protein relative to actin protein. Values are expressed as means \pm S.E.M. in arbitrary optical density units $(n=5)$. Bars with different superscripts are significantly different. Capital letters indicate $p<0.05$; ${ }^{* *} p<0.01$; ${ }^{* * *} p<0.001$. 
modulating its own receptor levels. In a study by Rodriguez-Pacheco et al. [21], a significant decrease in AdipoR1 mRNA levels and an increase in AdipoR2 mRNA concentrations was noted in cultures of rat pituitary cells exposed to $10^{-8} \mathrm{M}$ and $10^{-7} \mathrm{M}$ of adipokine for $24 \mathrm{~h}$, respectively. Data contrary to the above findings were reported by Caminos et al. [29] who observed a suppressing effect of adiponectin on AdipoR2 mRNA expression in cultured human placenta explants. The above results strongly suggest that steroids and other factors, including adiponectin itself, may affect the expression of adiponectin receptors in the pituitary.

Hormonal regulation of the adiponectin system is not limited to the receptors, and the production of adiponectin is also modified by steroid and protein hormones. Böttner et al. [37] demonstrated that serum adiponectin levels change between childhood and adulthood in a negative correlation with serum androgen levels. Elevated levels of adipokine were also reported in patients with hypogonadotropic hypogonadism and anorexia nervosa, whereas the administration of testosterone decreased adiponectin concentrations [38-40]. A similar relationship was observed in mice [41]. The role of oestrogens remains unclear. Inhibitory effects of oestradiol on plasma adiponectin in women and female ovariectomized rats [42-44] as well as lack of any action $[45,46]$ were both noted. Some data suggest that other factors, like prolactin, growth hormone, insulin or hCG also influence adiponectin expression [35,43,47].

The expression of both adiponectin receptors in the pituitary suggests that adiponectin has a local modulatory effect on central endocrine axes and that it participates in central control of metabolic homeostasis. In vitro studies seem to confirm this hypothesis. In a pituitary cell culture, short-term exposure $(4 \mathrm{~h})$ to the discussed hormone inhibited $\mathrm{LH}$ and $\mathrm{GH}$ release. Adiponectin reduced the stimulatory effect of $\mathrm{GnRH}$ on $\mathrm{LH}$ release, whereas $\mathrm{GH}$ release evoked by GHRH was not affected [21]. The above results were validated by $\mathrm{Lu}$ et al. [27] in whose study, adiponectin had an inhibitory effect on basal and GnRHstimulated $\mathrm{LH}$ release, but not on FSH release by L $\beta \mathrm{T} 2$ cells. The discussed findings seem to confirm the hypothesis that adiponectin is involved in auto-/paracrine control of pituitary functions.

Adiponectin may also act at the hypothalamic level. The expression of all adiponectin system components was observed in porcine hypothalamic structures responsible for $\mathrm{GnRH}$ secretion: the medio-basal hypothalamus $(\mathrm{MBH})$, preoptic area (POA) and median eminence (SME) (Kaminski et al., data not shown). Adiponectin receptors were also expressed in rat POA [48], as well as in the arcuate nucleus (ARH) and paraventricular hypothalamus (PVH) of mice [49]. The presence of AdipoRs was observed in magnocellular (oxytocin or vasopressin secreting) neurons of rat PVH [50]. Adiponectin's influence on the excitability of oxytocin-secreting neurons could explain enhanced oxytocin secretion in an obese population [50]. Globular adiponectin significantly decreased GnRH release in GT1-7 cells via AMPK activation. Specifically, low levels of adiponectin may contribute to chronically elevated LH levels [51]. The discussed research findings indicate that adiponectin may be an important factor which regulates pituitary functions directly as well as by modulating hypothalamic activity.

\section{Conclusions}

Our study was the first experiment to demonstrate the presence of AdipoR1 and AdipoR2 mRNAs and proteins in porcine pituitary and the effect of different stages of the oestrous cycle on the expression of both receptors. The presumable occurrence of AdipoRs in the pituitary suggests that adiponectin may affect reproductive functions by controlling the hypothalamic-pituitary-gonadal axis. Adiponectin's role in the anterior and posterior pituitary is poorly understood, and further work is needed to investigate its functions in detail.

\section{Competing interests}

The authors declare that they have no competing interests.

\section{Authors' contributions}

MK participated in design of the study, protein isolation, carried Western Blot analysis, prepared the statistical analysis and drafted the manuscript. AM participated in the mRNA and protein isolation, carried real-time analysis. AN collected the tissues, participated in mRNA and protein isolation. NS participated in the design of the study and coordination. TK conceived, designed and coordinated the study, helped to draft the manuscript. All authors read and approved the final manuscript.

\section{Acknowledgements}

This research was supported by National Science Centre (project no: 2011/ 01/B/NZ4/01596) and Ministry of Science and Higher Education (projects no: 528-0206.0805 and 528-0206.881).

Received: 30 November 2012 Accepted: 28 February 2013

Published: 5 March 2013

\section{References}

1. Hu E, Liang P, Spiegelman BM: AdipoQ is a novel adipose-specific gene dysregulated in obesity. J Biol Chem 1996, 271:10697-10703.

2. Maeda K, Okubo K, Shimomura I, Funahashi T, Matsuzawa Y, Matsubara K: cDNA cloning and expression of a novel adipose specific collagen-like factor, apM1 (AdiPose Most abundant Gene transcript 1). Biochem Biophys Res Commun 1996, 221:286-289.

3. Nakano Y, Tobe T, Choi-Miura NH, Mazda T, Tomita M: Isolation and characterization of GBP28, a novel gelatin-binding protein purified from human plasma. J Biochem 1996, 120:803-812.

4. Scherer PE, Williams S, Fogliano M, Baldini G, Lodish HF: A novel serum protein similar to $\mathrm{C} 1 \mathrm{q}$, produced exclusively in adipocytes. $J$ Biol Chem 1995, 270:26746-26749.

5. Arita Y, Kihara S, Ouchi N, Takahashi M, Maeda K, Miyagawa J, Hotta K Shimomura I, Nakamura T, Miyaoka K, Kuriyama H, Nishida M, Yamashita S, Okubo K, Matsubara K, Muraguchi M, Ohmoto Y, Funahashi T, Matsuzawa Y: Paradoxical decrease of an adipose-specific protein, adiponectin, in obesity. Biochem Biophys Res Commun 1999, 257:79-83.

6. Yamauchi T, Kamon J, Waki H, Terauchi Y, Kubota N, Hara K, Mori Y, Ide T, Murakami K, Tsuboyama-Kasaoka N, Ezaki O, Akanuma Y, Gavrilova O, Vinson C, Reitman ML, Kagechika H, Shudo K, Yoda M, Nakano Y, Tobe K, Nagai R, 
Kimura S, Tomita M, Froguel P, Kadowaki T: The fat-derived hormone adiponectin reverses insulin resistance associated with both lipoatrophy and obesity. Nat Med 2001, 7:941-946.

7. Kadowaki T, Yamauchi T, Kubota N, Hara K, Ueki K, Tobe K: Adiponectin and adiponectin receptors in insulin resistance, diabetes, and the metabolic syndrome. J Clin Invest 2006, 116:1784-1792.

8. Ouchi N, Kobayashi H, Kihara S, Kumada M, Sato K, Inoue T, Funahashi T, Walsh K: Adiponectin stimulates angiogenesis by promoting cross-talk between AMP-activated protein kinase and Akt signaling in endothelial cells. J Biol Chem 2004, 279:1304-1309.

9. Trujillo ME, Scherer PE: Adiponectin-journey from an adipocyte secretory protein to biomarker of the metabolic syndrome. J Intern Med 2005, 257:167-175.

10. Yamauchi T, Kamon J, Minokoshi Y, Ito Y, Waki H, Uchida S, Yamashita S, Noda M, Kita S, Ueki K, Eto K, Akanuma Y, Froguel P, Foufelle F, Ferre P, Carling D, Kimura S, Nagai R, Kahn BB, Kadowaki T: Adiponectin stimulates glucose utilization and fatty-acid oxidation by activating AMP-activated protein kinase. Nat Med 2002, 8:1288-1295.

11. Kobashi C, Urakaze M, Kishida M, Kibayashi E, Kobayashi H, Kihara S, Funahashi T, Takata M, Temaru R, Sato A, Yamazaki K, Nakamura N, Kobayashi M: Adiponectin inhibits endothelial synthesis of interleukin-8. Circ Res 2005, 97:1245-1252.

12. Barb D, Pazaitou-Panayiotou K, Mantzoros CS: Adiponectin: a link between obesity and cancer. Drugs 2006, 15:917-933.

13. Brochu-Gaudreau K, Rehfeldt C, Blouin R, Bordignon V, Murphy BD, Palin MF: Adiponectin action from head to toe. Endocrine 2010, 37:11-32.

14. Yamauchi T, Kamon J, Ito Y, Tsuchida A, Yokomizo T, Kita S, Sugiyama T, Miyagishi M, Hara K, Tsunoda M, Murakami K, Ohteki T, Uchida S, Takekawa S, Waki H, Tsuno NH, Shibata Y, Terauchi Y, Froguel P, Tobe K, Koyasu S, Taira K, Kitamura T, Shimizu T, Nagai R, Kadowaki T: Cloning of adiponectin receptors that mediate antidiabetic metabolic effects. Nature 2003, 423:762-769.

15. Lord E, Ledoux S, Murphy D, Beaudry D, Palin MF: Expression of adiponectin and its receptors in swine. J Anim Sci 2005, 83:565-578.

16. Ramachandran R, Ocon-Grove OM, Metzger SL: Molecular cloning and tissue expression of chicken AdipoR1 and AdipoR2 complementary deoxyribonucleic acids. Domest Anim Endocrinol 2007, 33:19-31.

17. Hug C, Wang J, Ahmad NS, Bogan JS, Tsao TS, Lodish HF: T-cadherin is a receptor for hexameric and high-molecular-weight forms of Acrp30/ adiponectin. Proc Natl Acad Sci U S A 2004, 101:10308-10313.

18. Neumeier M, Weigert J, Buettner R, Wanninger J, Schäffler A, Müller AM, Killian S, Sauerbruch S, Schlachetzki F, Steinbrecher A, Aslanidis C, Schölmerich J, Buechler C: Detection of adiponectin in cerebrospinal fluid in humans. Am J Physiol Endocrinol Metab 2007, 293:E965-E969.

19. Psilopanagioti A, Papadaki H, Kranioti EF, Alexandrides TK, Varakis JN: Expression of adiponectin and adiponectin receptors in human pituitary gland and brain. Neuroendocrinology 2009, 89:38-47.

20. Steyn FJ, Boehme F, Vargas E, Wang K, Parkington HC, Rao JR, Chen C: Adiponectin regulate growth hormone secretion via adiponectin receptor mediated $\mathrm{Ca}(2+)$ signalling in rat somatotrophs in vitro. J Neuroendocrinol 2009, 21:698-704.

21. Rodriguez-Pacheco F, Martinez-Fuentes AJ, Tovar S, Pinilla L, Tena-Sempere M, Dieguez C, Castaño JP, Malagon MM: Regulation of pituitary cell function by adiponectin. Endocrinology 2007, 148:401-410.

22. Akins EL, Morrissette MC: Gross ovarian changes during oestrous cycle of swine. Am J Vet Res 1968, 29:1953-1957.

23. Nitkiewicz A, Smolinska N, Maleszka A, Kiezun M, Kaminski T: Localization of orexin A and orexin B in the porcine uterus. Reprod Biol 2012, 12:135-155.

24. Henricks DM, Guthrie HD, Handlin DL: Plasma estrogen, progesterone and luteinizing hormone levels during the oestrous cycle in pigs. Biol Reprod 1972, 6:210-218.

25. Livak KJ, Schmittgen TD: Analysis of relative gene expression data using real-time quantitative PCR and the 2(-Delta Delta C(T)) Method. Methods 2001, 25:402-408

26. Smolinska N, Kaminski T, Siawrys G, Przała J: Long form of lepton receptor gene and protein expression in the porcine ovary during the oestrous cycle and early pregnancy. Reprod Biol 2007, 7:17-39.

27. Lu M, Tang Q, Olefsky JM, Mellon PL, Webster NJ: Adiponectin activates adenosine monophosphate-activated protein kinase and decreases luteinizing hormone secretion in LbetaT2 gonadotropes. Mol Endocrinol 2008, 22:760-771.
28. Takemura Y, Osuga Y, Yamauchi T, Kobayashi M, Harada M, Hirata T, Morimoto C, Hirota Y, Yoshino O, Koga K, Yano T, Kadowaki T, Taketani Y: Expression of adiponectin receptors and its possible implication in the human endometrium. Endocrinology 2006, 147:3203-3210.

29. Caminos JE, Nogueiras R, Gallego R, Bravo S, Tovar S, García-Caballero T, Casanueva FF, Diéguez C: Expression and regulation of adiponectin and receptor in human and rat placenta. J Clin Endocrinol Metab 2005, 90:4276-4286.

30. Tabandeh MR, Hosseini A, Saeb M, Kafi M, Saeb S: Changes in the gene expression of adiponectin and adiponectin receptors (AdipoR1 and AdipoR2) in ovarian follicular cells of dairy cow at different stages of development. Theriogenology 2010, 73:659-669.

31. Lagaly DV, Aad PY, Grado-Ahuir JA, Hulsey LB, Spicer LJ: Role of adiponectin in regulating ovarian theca and granulosa cell function. $\mathrm{Mol}$ Cell Endocrinol 2008, 284:38-45.

32. Tan BK, Chen J, Digby JE, Keay SD, Kennedy CR, Randeva HS: Upregulation of adiponectin receptor 1 and 2 mRNA and protein in adipose tissue and adipocytes in insulin-resistant women with polycystic ovary syndrome. Diabetologia 2006, 49:2723-2728.

33. Wen $Y$, Wang H, MacLaren R, Lu H, Hu XF, Cianflone K: Sex steroid hormones induce acylation stimulating protein resistance in 3 T3-L1 adipocytes. J Cell Biochem 2008, 105:404-413.

34. Tsuchida A, Yamauchi T, Ito Y, Hada Y, Maki T, Takekawa S, Kamon J, Kobayashi M, Suzuki R, Hara K, Kubota N, Terauchi Y, Froguel P, Nakae J, Kasuga M, Accili D, Tobe K, Ueki K, Nagai R, Kadowaki T: Insulin/Foxo1 pathway regulates expression levels of adiponectin receptors and adiponectin sensitivity. J Biol Chem 2004, 279:30817-30822.

35. Nilsson L, Binart N, Bohlooly-Y M, Bramnert M, Egecioglu E, Kindblom J, Kelly PA, Kopchick JJ, Ormandy CJ, Ling C, Billig H: Prolactin and growth hormone regulate adiponectin secretion and receptor expression in adipose tissue. Biochem Biophys Res Commun 2005, 331:1120-1126.

36. Chen J, Tan B, Karteris E, Zervou S, Digby J, Hillhouse EW, Vatish M, Randeva HS: Secretion of adiponectin by human placenta: differential modulation of adiponectin and its receptors by cytokines. Diabetologia 2006, 49:1292-1302.

37. Böttner A, Kratzsch J, Müller G, Kapellen TM, Blüher S, Keller E, Blüher M, Kiess W: Gender differences of adiponectin levels develop during the progression of puberty and are related to serum androgen levels. J Clin Endocrinol Metab 2004, 89:4053-4061.

38. Lanfranco F, Zitzmann M, Simoni M, Nieschlag E: Serum adiponectin levels in hypogonadal males: influence of testosterone replacement therapy. Clin Endocrinol (Oxf) 2004, 60:500-507.

39. Modan-Moses D, Stein D, Pariente C, Yaroslavsky A, Ram A, Faigin M, Loewenthal R, Yissachar E, Hemi R, Kanety H: Modulation of adiponectin and leptin during refeeding of female anorexia nervosa patients. J Clin Endocrinol Metab 2007, 92:1843-1847.

40. Page ST, Herbst KL, Amory JK, Coviello AD, Anawalt BD, Matsumoto AM, Bremner WJ: Testosterone administration suppresses adiponectin levels in men. J Androl 2005, 26:85-92.

41. Nishizawa H, Shimomura I, Kishida K, Maeda N, Kuriyama H, Nagaretani H, Matsuda M, Kondo H, Furuyama N, Kihara S, Nakamura T, Tochino Y, Funahashi T, Matsuzawa Y: Androgens decrease plasma adiponectin, an insulin-sensitizing adipocyte-derived protein. Diabetes 2002, 51:2734-2741.

42. Kafkas S, Dost T, Ozkayran H, Yenisey C, Tuncyurek P, Birincioglu M: Effect of estrogen therapy on adipocytokines in ovariectomized-aged rats. J Obstet Gynaecol Res 2012, 38:231-238.

43. Liu YH, Tsai EM, Chen YL, Chen HS, Chen YC, Wu LC, Lee CH, Jong SB, Chan TF: Serum adiponectin levels increase after human chorionic gonadotropin treatment during in vitro fertilization. Gynecol Obstet Invest 2006, 62:61-65.

44. Tamakoshi K, Yatsuya H, Wada K, Matsushita K, Otsuka R, Yang PO, Sugiura K, Hotta Y, Mitsuhashi H, Takefuji S, Kondo T, Toyoshima H: The transition to menopause reinforces adiponectin production and its contribution to improvement of insulin-resistant state. Clin Endocrinol (Oxf) 2007, 66:65-71.

45. Chalvatzas N, Dafopoulos K, Kosmas G, Kallitsaris A, Pournaras S, Messinis IE: Effect of ovarian hormones on serum adiponectin and resistin concentrations. Fertil Steril 2009, 91:1189-1194.

46. Dafopoulos K, Sourlas D, Kallitsaris A, Pournaras S, Messinis IE: Blood ghrelin, resistin, and adiponectin concentrations during the normal menstrual cycle. Fertil Steril 2009, 92:1389-1394. 
47. Seale AP, de Jesus LA, Park MC, Kim YS: Vanadium and insulin increase adiponectin production in 3 T3-L1 adipocytes. Pharmacol Res 2006, 54:30-38.

48. Klein I, Sanchez-Alavez M, Tabarean I, Schaefer J, Holmberg KH, Klaus J, Xia F, Marcondes MC, Dubins JS, Morrison B, Zhukov V, Sanchez-Gonzalez A, Mitsukawa K, Hadcock JR, Bartfai T, Conti B: AdipoR1 and 2 are expressed on warm sensitive neurons of the hypothalamic preoptic area and contribute to central hyperthermic effects of adiponectin. Brain Res 2011, 1423:1-9.

49. Kubota N, Yano W, Kubota T, Yamauchi T, Itoh S, Kumagai H, Kozono H, Takamoto I, Okamoto S, Shiuchi T, Suzuki R, Satoh H, Tsuchida A, Moroi M, Sugi K, Noda T, Ebinuma H, Ueta Y, Kondo T, Araki E, Ezaki O, Nagai R, Tobe K, Terauchi Y, Ueki K, Minokoshi Y, Kadowaki T: Adiponectin stimulates AMP-activated protein kinase in the hypothalamus and increases food intake. Cell Metab 2007, 6:55-68.

50. Hoyda TD, Fry M, Ahima RS, Ferguson AV: Adiponectin selectively inhibits oxytocin neurons of the paraventricular nucleus of the hypothalamus. J Physiol 2007, 585:805-816.

51. Wen JP, Lv WS, Yang J, Nie AF, Cheng XB, Yang Y, Ge Y, Li XY, Ning G. Globular adiponectin inhibits GnRH secretion from GT1-7 hypothalamic $\mathrm{GnRH}$ neurons by induction of hyperpolarization of membrane potential. Biochem Biophys Res Commun 2008, 371:756-761.

doi:10.1186/1477-7827-11-18

Cite this article as: Kiezun et al:: Expression of adiponectin receptors 1

(AdipoR1) and 2 (AdipoR2) in the porcine pituitary during the oestrous cycle. Reproductive Biology and Endocrinology 2013 11:18.

\section{Submit your next manuscript to BioMed Central and take full advantage of:}

- Convenient online submission

- Thorough peer review

- No space constraints or color figure charges

- Immediate publication on acceptance

- Inclusion in PubMed, CAS, Scopus and Google Scholar

- Research which is freely available for redistribution 